\title{
Direct Participation of Citizen in Democratic Decision Making at the Local Level
}

\author{
PhD (c) Ramiz Fazliu \\ College "ILIRIA" Pristina
}

\begin{abstract}
The Essence every proper democracy is characterized by the level of participation of citizens in decision-making for different local issues and affairs. The right of direct participation of citizens in decision-making on local issues proclaimed even by the norms prescribed by domestic legal frame (countries apart) but also internationally, which determine in an almost standardize form the participation of citizens in decision-making such as civic initiatives, gatherings of citizens, referendum, public audience, polls, surveys, petitions etc. Through these forms of participation citizens are directly involved in making decisions about local affairs and issues related to the life and the common interests of the local level. Therefore, people with their participation can influence in decision-making in various fields, such as, in the area of decision-making for local policies dealing with legal acts (regulations and other local acts), plans and programs, as well as concrete development projects at the local level. The object of this paper deals with the most common forms of citizen's participation in decision making at the local level which are illustrated with some concrete examples on how is regulated by legal norms and practically implemented in some countries with developed democracies: the USA, Great Britain, Switzerland and the countries of Central and Southeastern Europe such as Estonia, Hungary, Kosovo.
\end{abstract}

Keywords: citizen, participation, establishment, law, local self-government, referendum.

\section{Introduction}

The first level where the democracy begins and testes is exactly the local government, precisely the first level of local government. Local government is the first gate where the citizen has the chance to be active in local government unit and get the necessary experience to participate in higher levels and develop the democratic and political culture.

In order to achieve this, the citizen shall be provided these three basic conditions:

1. If the citizen is guaranteed the legal framework of the right to participate in decision-making on local character;

2. If the local authorities have the political will to implement the legal framework and

3. If there is awareness and readiness of the citizen for using his rights to affect local decision - making.

The right on local self-government or its participation whether direct or indirect citizens in deciding on public affairs of common interest it is provided not only by national legislation (Constitution ${ }^{1}$, law, statute) but also by the European Charter on local self-government ${ }^{2}$, which defines local self-government as a group of local institutions that have the right but also the obligation that certain citizens of the local community to enable, directly or through their representatives, to govern certain public affairs relatively in independent manner, in their own responsibility and for their own interests. The participatory approach of policymaking and lawmaking at EU and Member States also is rooted in the Lisbon Treaty ${ }^{3}$. More specifically, Article 10 provides that "every citizen has the right to 'participation in the democratic life of EU; decisions will be taken in the most transparent and as close to the citizen ".

1 The Constitution of the Republic of Kosovo, Pristina, 2008 Section, 2,123,124.

2 European Charter of Local Self-Government, adopted by the Council of Europe in 1985, Strasbourg

3 The consolidated version of the Treaty on European Union; http // eur-lex.europa.eu 


\section{The forms of direct participation of citizens in the democratic decisions}

Every proper democratic system of local self-government to perform its functions and to meet the set out democratic principles is obliged to incorporate forms of direct participation of citizens in the decision-making process on local importance issues. Since citizens have no legal forum to decide on various issues, the possibility of their involvement in the process of establishing democratic forms and their participation in almost all systems of local self-government is regulated by the provisions of constitution, law and statute local self-government unit.

Since the regulation of local self-government system varies from one country to another, the framework of forms for democratic participation of citizens is changing, not only by their volume, but also the manner of organization, depends as required by legal regulations.

The most characteristic and frequent forms of participation of citizens in the process of direct democracy, which enable the participation in local affairs, to decide in the unit of local self-government, especially in the matters of meeting the daily needs are: public polls (surveys), civic initiative, public audience, gatherings of citizens referendum and also other forms, such as petition and complaint.

\subsection{Public Polls (surveys)}

To decide on local issues there are several public opinion surveys organized on specific issues. Through these surveys for a certain issue, citizens are asked directly. Citizens' opinions can be expressed instantly, orally or in writing, for specific issues. This form of citizen participation in the process of decision is made in order to gather the opinions of citizens, ordinary or representative category, to clarify any political event, economic issues or other matters of general interest. For example, public opinion is required for the initiative, adoption, amendment or cancellation of a legal act of the municipal council or executive body of the municipality.

Usually, public opinion polls are organized via public media (newspapers, radio, television, electronic portals, but not ruled out other forms, such as specialized companies dealing with this activity.

The survey of public opinion as a form of citizen participation in the decision making process on local issues, practiced in almost all the countries with a developed democracy. Thus, for example, in Estonia this form is justified as: "To decide on local issues can be public opinion polls or a referendum. At least $1 \%$ of citizens of the local unit, but not more than $5 \%$ of its inhabitants, can vote, have the right of initiative for the approval, modification or cancelation of a legal act of the Council, or executive local government ${ }^{1}$. "It is common practice that the results of the survey are published, or presented in written (the report) to the relevant authority for the thoughts and decisions arising from the implementation of specific survey.

\subsection{Civic Initiative (people)}

Civic Initiative (people), as a democratic institution, is old and known since ancient Greece, as vox populi- as the voice of the people as a form of democratic expression. Even though the range of involvement of the scope of functions and duties of local governments is large, for some cases with interest, bodies of this level of government cannot, or do not need to solve at certain moments, in cases when they are not in their competence, they are not included in the work plan, annual budget, or activity program, then these bodies pursue alternative way, for certain issues want to listen the voice of the people, which is their desire and determination of the matter.

The difference to the survey, which comes and reflects by the certain body of the relevant local government unit (the Council or the Executive Body), the initiative comes from the citizens, as a form of democratic expression. Initiative should be understood, primarily, as interest, which is a reflection and an opposite direction from the definition of local government; its purpose is to meet or conduct public affairs in the interest of the local population. People initiatives often can not be limited 
to local boundaries, because sometimes it exceeds these limits. This primarily depends on the purpose of the request submitted and the level of its completion.

Civic initiatives as a form of democratic expression is known almost in all democratic countries, but it is more expressed in the USA, often known as a petition. Thus, "a group of people formulate a joint proposal, which convey a significant number of signatures also other people and address the representative body to decide on the proposal" ${ }^{1}$. Through this form, which in Anglo-Saxon countries, in particular in the USA, citizens regulate issues of local concern mainly in the cities, where the local administration (government) doesn't pay any special importance to certain issues, which remain to be initiated by the citizens.

People initiatives as a form of democratic expression and opportunity to achieve certain goals of citizens interest, among countries with developed democratic system, is practiced in all countries of Eastern Europe that passed the transition. This form of citizen participation is already a legal category as well, e.g. In Hungary, the people initiative is provided by the special provision, under which: "It is possible that people initiative to be submitted to the Council related to any matter of the scope of its authority. The electorate $5-10 \%$ of voters may file the people initiative to the mayor. It is his obligation to discuss and decide on the people initiative at his closest meeting "2. Even with the Law on Local Self-Government in Kosovo, the Citizens' Initiative is regulated by the Article70. which allows citizens to take initiatives for local issues, but must be signed by $15 \%$ of the registered electorate in the certain municipality.

\subsection{Public Audience}

Public audience, as a new form of democratic expression, is mainly related to the corresponding activity and the way of solutions to numerous problems that concern citizens locally. It is the practice in almost all local governance systems; local government authorities (in most of the cases mayors) organize public audiences, where citizens and representatives of local organizations can ask questions and have proposals on issues of public interest.

This is a form of expression, where citizens can directly engage in the nomination process, but also the determination of the public interest issues. Thus, the public audience now cannot be understood only as a matter of politeness and courtesy, which at some time characterized spiritual leaders, or leaders. Public audience, as a democratic institution, has taken the form of a mandatory legal provision at the local level, not only in countries with developed democracy but also in other countries that successfully passed the democratic transition. Thus, by the law on municipalities in Hungary, there is a provision with special regard which regulates the form of organization and holding the public audiences. With this provision, "The Council, after being notified in advance, invites citizens in public audiences to local officials-mayor, which are mandatory required to be held once a year." 3

Even with the Law on Local Self Government of Kosovo, the issue of public audience is regulated by Article 68 where the mayor is obliged twice a year to organize public meetings with citizens ${ }^{4}$, where they will be informed about projects and achievements and hearing the concerns and proposals of citizens on local issues.

\subsection{Assemblies of citizens}

The institution of the direct participation of citizens in the process of determination, is known since Ancient Greece (assemblies of polisis), but as the most expressed form is still practiced in the Great Britain as "Town Assembly " which usually takes part once or twice a year in the parishes, which count under 300 residents, and do not have a chosen representative body (designated elders) 5 . In these assemblies, the citizens except making decisions on numerous issues, they also elect the chairman of the parish, which is usually the executive body.

1 Same there

2 Same there. pg. 98

33 Same there. pg. 100

4 Law on Local Self-Government in Republic of Kosovo, 2008. Article 70

5 Vojislav Simovic, Municipal system and municipal politics, Prishtina, 1972, pg.86 
Meanwhile, in the USA, the institution is known as "town meeting" This is in fact a special annual assembly of qualified electors. These electors gathered in the meeting, constitute the elected "legislator" body. The assembly approves basic decisions on the "politics" of the city, electing local officials, confirms the budget, approves the amount of fees, approves decisions on referendums etc. ${ }^{1}$

It is worth to underline that the decisions in the citizen's assembly are approved by majority in public form.

It is a practice that the forms of citizen's assemblies are regularly used for public discussion on the occasion of proposed projects and plans, as well as systemic ones, as well as development plans at the local level and beyond. This form of citizen participation in the decision-making process is the most common form practiced as a democratic form of direct selfgovernment at the local level.

\subsection{Referendum}

The referendum is the most preferred among democratic forms where citizens directly decide important issues and specific problems of a self-government unit. The referendum is public, with the participation of all citizens which enjoy the right of vote. The rules of the referendum shall be determined by law ${ }^{2}$, depending on the issues raised and which have to be approved directly by citizens, members of an organization etc.

Legal and constitutional theory recognizes three forms of the referendum such as:

$$
\begin{aligned}
& \text {-State -Referendum } \\
& \text {-Local -Referendum } \\
& \text {-Consultative - optional Referendum }
\end{aligned}
$$

As for the matter of the issue to be decided by referendum we can distinguish: the constitutional referendum (approval of the constitution), the law referendum (approval of the law), local referendum - direct placement for any act or decision within the self-governing unit, or adoption of any document or act of an enterprise or organization (political, trade unions etc.) institution, optional and consultative referendum.

Initiative and the decision on the referendum is taken by the competent authority for approval of the decision to go for the referendum (mostly Parliament), or by the request of citizens (a right that is recognized to a certain number), depending on how it is foreseen by the constitution or law.

Through the referendum, citizens by secret vote shall be determined pro or contra the preliminary submitted proposal. The decision taken by referendum is obligatory for the organ, which has declared the referendum. The question is what pushes representative bodies, or even its own citizens to undertake an initiative of organizing a referendum? The motives can be different and diverse. In this case we will mention three as the most common: first, if an issue cannot be resolved in regular procedure (e.g. In the municipal councils-City), but the question remains open (contest open). This contest is followed in arbitration solution to all citizens of certain territory, then through a referendum; Secondly, if an issue is too important for local government and with the risk of failure of the decision by the representative organ, then this issue is forwarded for the referendum and thirdly, the motive may be of political nature which is more often when resolving any vital but also sensitive issues (national aspect, religious, gender, etc.) to certain citizens of the local unit, or even wider. Also, the results of the referendum are often exploited and use as political guidelines for the serving leader to make decisions of a political nature, for example the announcement of early elections.

With the referendum can be raised all the issues with economic character, legal and political, and the final decision is whether the majority voted "pro" the proposal, actually over $50 \%$ of the total number of citizens eligible to vote in the referendum. It is the practice of many countries that by law is foreseen a series cases, where a referendum may be required.

1 Same there. pg. 87

2 In Referendum is decided by the absolute majority of voters who have been in a referendum, provided that in referendum has participated majority of the voters registered in the local government unit. 
Regarding the organization and holding of referendums, especially for local issues, Switzerland and the Scandinavian countries are more well-known in this matter.

\subsection{Other forms of participation of citizens}

Through the forms of direct determination and declaration, the citizens can participate in local self-government through signature of lists for candidates (independent) of citizens in local elections, petitions, proposals and complaints. These forms of participation or declaration of citizens are regulated by law or other acts of local self-government units (statute, regulation).

The lists of candidates (independent) of citizens for local elections - is a more frequent form and in increasing trend of participation of citizens or groups of citizens to participate in local elections for representative bodies or candidates for the Executive Body (head union-mayor), in local self-government systems, which is elected by direct elections. Through this form of participation and determining the election of their candidates, rather than political parties, citizens are justified by the fact that their candidates represent their interest better towards local authority than candidates who hold the guise of a political party, which represents in these bodies, where on their decisions, quite often they have justification conform their political entity status.

Petition- is a form of reaction or "protest in writing" through which citizens ask the competent authority to take necessary measures in order to solve the problem determined at the local level. The petition is usually filed-arranged by a certain group of people, which organizes the activity of collecting signatures for it. The procedure of filing a petition is provided by law or the statute of self-government unit. The law also defines the time limits within the petition is organized and the body who is obliged to take the decision and give the response to the applicants of the petition.

Complained- is an individual or collective action where a citizen or group of citizens can complain about providing or not providing proper quality of public services. Every citizen has the right to complain to the competent authority at the local government unit. The procedure of filing complaint is regulated by law or municipal normative act. After filing the complaint, the body to which the complaint is filed is obliged to examine and decide (within 30 days) and return the answer to the complainant or group of complainants about its decision on the issue that was the subject of complaint

\section{Literature}

Constitution of Republic of Kosovo, 2008

Consolidated version of European Treaty; http/leur-lex.europa.eu

European Charter on Local Self-government, Strasburg, 1985

Local governments in Central and Eastern Europe and in the community of independent states. Anthology of the Institute for Local Self-Government and public services, Budapest, 1994

The Law on Local Self-government of Republic of Kosovo, 2008.

Vojislav Simovic, Municipal system and municipal politics, Prishtina, 1972, 